\title{
Stabilitas Pemerintahan Pasca Pemilihan Umum di Indonesia antara Checks and Balances dan Demokrasi Transaksional
}

\author{
${ }^{1}$ Fuqoha, ${ }^{2}$ Arif Nugroho, ${ }^{3}$ Indrianti Azhar Firdausi \\ Fakultas Ilmu Sosial, Ilmu Politik Dan Ilmu Hukum, Universitas Serang Raya, Serang. \\ Email : fuqoha23@gmail.com
}

Info Artikel:

| Diterima: 20 Desember 2019

| Disetujui: 30 Desember 2019

| Dipublikasikan: 31 Desember 2019

\begin{abstract}
Realizing of implementation a democratic State, in Indonesian constitutional system is prepared by principles of constitutional democracy. The principle of constitutional democracy is carried out with the intention of implementing a democratic system with limited by constitution. Among the principles of democracy are the electoral system to elect State leaders and people's representatives. Good government will creation a government stability and political stability in realizing the goals and ideals of the State through the concept of checks and balances. The conception of checks and balances in a democratic frame can be realized with the principles of transformative democracy and / or transactional democracy. In the constitution of Indonesia, the principle of transactional democracy can occur before and after the general election of the President and Vice President. Transactional democracy can threaten government and / or political stability if group / coalition solidity is not created in carrying out checks and balances.
\end{abstract}

Keywords: Stability; General election; Checks and Balances; Democracy; Transactional

\begin{abstract}
Abstrak
Dalam mewujudkan penyelenggaraan Negara yang demokratis, maka sistem ketatanegaraan Indonesia disusun dengan menganut prinsip demokrasi konstitusional. Prinsip demokrasi konstitusional diselenggarakan dengan maksud melaksanakan sistem pemerintahan yang demokratis dengan dibatasi konstitusi. Diantara prinsip demokrasi yaitu sistem pemilihan umum untuk memilih pemimpin Negara dan wakil rakyat di pemerintahan. Penyelenggaraan Negara terlihat baik manakala terciptanya stabilitas pemerintah dan stabilitas politik dalam mewujudkan tujuan dan cita-cita Negara melalui konsep checks and balances. Konsepsi checks and balances dalam bingkai demokrasi dapat diwujudkan dengan prinsip demokrasi transformatif dan/atau demokrasi transaksional. Dalam ketentuan konstitusi Negara Indonesia, prinsip demokrasi transaksional dapat terjadi pada saat sebelum dan sesudah pemilihan umum Presiden dan wakil Presiden. Demokrasi transaksional dapat mengancam stabilitas pemerintahan dan/atau politik jika tidak terciptanya soliditas kelompok/koalisi dalam melaksanakan fungsi checks and balances.
\end{abstract}

Kata Kunci : Stabilitas; Pemilihan Umum; Checks and Balances; Demokrasi; Transaksional 


\section{A. PENDAHULUAN}

Sistem Ketatanegaraan Indonesia menganut prinsip demokrasi konstitusional yang mengandung nilai bahwa penyelenggaraan Negara demokratis yang dibatasi oleh konstitusi atau Undang-Undang Dasar 1945. Dalam rangka penyelenggaraan Negara yang demokratis, konstitusi Republik Indonesia secara normatif mengandung prinsip trias politika yang dikemukakan oleh John Locke dan Monstequieu dalam konsep pemisahan kekuasaan (separation of power). Konsepsi trias politika tersebut memisahkan kekuasaan kedalam tiga bentuk rule making function, rule application function dan rule adjudication function. ${ }^{1}$

Konsepsi pemisahan kekuasaan tersebut secara normatif dalam bingkai konstitusi memberikan kepastian hukum dalam penyelenggaraan pemerintahan secara konstitusional. Dengan diaturnya ketentuan dalam konstitusi, maka lembaga-lembaga tersebut memiliki kekuasaan serta kewenangan untuk melaksanakan tugas dan fungsi. Konsepsi trias politika dalam sistem ketatanegaraan Indonesia tercermin dalam UndangUndang Dasar Negara Republik Indonesia 1945 yang tercermin dalam BAB III tentang Kekuasaan Pemerintahan Negara sebagai konsep rule application function. Kemudian konsep rule making function dituangkan dalam BAB VII dan BAB VIIA yang mengamanatkan kekuasaan pada Dewan Perwakilan Rakyat (DPR) dan Dewan Perwakilan Daerah (DPD). Sedangkan konsep rule adjudication function dituangkan dalam BAB IX tentang Kekuasaan Kehakiman.

Pemisahan kekuasaan (separation of power) yang ditawarkan dalam konsep trias politika menghendaki penyelenggaraan yang berkeadilan dalam rangka terpenuhinya hak-hak rakyat dari absolutisme kekuasaan (otoritarian). Pada hakikatnya pemisahan kekuasaan menghendaki penyelenggaraan kekuasaan Negara tidak dilaksanakan oleh satu orang yang dapat mengarah pada penyalahgunaan kekuasaaan (abuse of power). Oleh karena itu, sistem ketatanegaran Indonesia secara normatif telah mengatur penyelenggaraan Negara yang terbebas dari upaya penyalahgunaan kekuasaan dengan membagi kekuasaan tersebut dalam beberapa kelembagaan sesuai dengan fungsinya masing-masing.

Dalam melaksanakan konsepsi pemisahan kekuasaan dalam amanat konstitusi yang memberikan kekuasaan dan kewenangan pada institusi dan/atau organ tersebut perlu diberlakukan sistem pengawasan dan keseimbangan (checks and balances) yang saling mengawasi dan mengimbangi kekuasaan satu dan lainnya sebagai pembatas kekuasaan tiap organ dan/atau institusi terhadap kekuasaan yang dimilikinya. ${ }^{2}$ Hal tersebut mengindikasikan adanya hubungan satu organ/institusi dengan organ/institusi lainnya dalam penyelenggaran pemerintahan. Tujuannya adalah menjaga stabilitas pemerintahan dalam mencapai tujuan-tujuan dan citacita Negara agar terselenggara tanpa

\footnotetext{
${ }^{1}$ Miriam Budiardjo, Dasar-Dasar Ilmu Politik, Revisi (Jakarta: Gramedia Pustaka Utama, 2008). hlm 281
}

${ }^{2}$ Ibid. hlm. 284 
adanya penyalahgunaan kekuasaan dalam bingkai Negara demokrasi.

Kekuasaan dalam konsep rule application function memberikan kewenangan kepada pemerintah dan/atau Presiden sebagai kepala pemerintahan dalam sistem ketatanegaraan Indonesia untuk melaksanakan kebijakan dalam rangka mencapai tujuan-tujuan Negara. Berdasarkan pada ketentuan UndangUndang Dasar 1945 dalam Pasal 4 Ayat (1) bahwa Presiden Republik Indonesia memegang kekuasaan pemerintahan beradasrkan pada Undang-Undang Dasar. Presiden juga memiliki kewenangan untuk mengusulkan Rancangan UndangUndang bahkan mengeluarkan Peraturan Pemerintah Pengganti Undang-Undang (Perppu) apabila ada undang-undang yang dinilai genting menurut Presiden. Kekuasaan pemerintah, dalam hal ini Presiden dan/atau wakil Presiden sebagai fungsi pelaksana penyelenggara Negara dapat saling mempengaruhi dalam sistem checks and balances. Dengan demikian pola hubungan kekuasaan eksekutif dan legislatif saling bersinggungan dan dapat saling mengintervensi kepentingan satu dengan lainnya yang dapat mengakibatkan instabilitas pemerintahan.

Pola hubungan kekuasaan dalam sistem checks and balances dalam sistem ketatanegaraan Indonesia lebih lanjut diatur melalui peraturan perundangundangan yang mengatur kekuasaan dan kewenangan tiap-tiap lembaga/institusi yang dituangkan dalam Pasal 7A Undang-Undang Dasar 1945 dan Undang-Undang Nomor 17 Tahun 2014 yang mengatur kekuasaan dan kewenangan legislatif sebagai rule making function yang diantaranya mengatur kewenangan Majelis Permusyawaratan Rakyat (MPR), Dewan Perwakilan Rakyat (DPR), Dewan Perwakilan Daerah (DPD) dan Dewan Perwakilan Rakyat Daerah (DPRD). Berdasarkan kewenangan yang diberikan oleh konstitusi dan peraturan perundangundangan, maka lembaga legislatif dapat melakukan fungsi yang salah satunya adalah fungsi pengawasan terhadap kinerja pemerintah (lembaga eksekutif dan yudikatif). Berdasarkan kewenangan yang diberikan legislatif (MPR dan/atau DPR dan DPD) dapat memberhentikan eksekutif (presiden dan/atau wakil presiden) serta mempertimbangkan pengisian jabatan dalam kekuasaan kehakiman (yudikatif).

Konsepsi rule adjudication function sebagai kewenangan yudikatif terhadap sistem checks and balances diantaranya adalah kewenangan untuk pengujian undang-undang (judicial review) atas undang-undang yang dikeluarkan oleh legislatif. Dengan demikian, peraturan perundang-undangan yang disusun dan/atau disahkan oleh legislatif dapat dibatalkan sebagian dan/atau seluruhnya oleh lembaga yudikatif berdasarkan ketentuan perundang-undangan Nomor 14 Tahun 1985 tentang Mahkamah Agung sebagaimana telah dirubah dengan Undang-Undang Nomor 3 Tahun 2009 tentang Perubahan Kedua atas UndangUndang Nomor 14 Tahun 1985 tentang Mahkamah Agung yang memberikan kewenangan untuk menguji undangundang terhadap undang-undang. Serta melalui ketentuan dalam Undang-Undang Nomor 23 Tahun 2004 tentang Mahkamah Konstitusi sebagaimana 
diubah dengan Peraturan Pemerintah Pengganti Undang-Undang Nomor 1 Tahun 2013 tentang Perubahan Kedua atas Undang-Undang Nomor 24 Tahun 2003 tentang Mahkamah Konstitusi sebagaimana ditetapkan dalam UndangUndang Nomor 4 Tahun 2014 tentang Penetapan Peraturan Pemerintah Pengganti Undang-Undang Nomor 1 Tahun 2013 tentang Perubahan Kedua atas Undang-Undang Nomor 24 Tahun 2003 tentang Mahkamah Konstitusi yang memberikan kewenangan untuk menguji undang-undang terhadap UndangUndang Dasar 1945.

Mekanisme pelaksanaan trias politika dalam penyelenggaraan Negara di Indonesia bertujuan untuk menciptakan efektifitas pemerintahan dan stabilitas politik. Dinamika politik di Indonesia pasca pemilihan umum selalu menampilkan dominasi kekuasaan antara legislatif dan eksekutif. Persoalan yang timbul dari kedua lembaga tersebut mengikis makna konsep trias politika sebagai pemisah kekuasaan (separation of power) yang bergerser pada pembagian kekuasaan (division of power). ${ }^{3}$ Pasca reformasi, kelembagaan legislatif dan eksekutif semakin bersinggungan dengan kekuasaan dan kewenangan yang melekat pada lembaga legislatif yang mengawasi kinerja eksekutif maupun eksekutif yang memiliki fungsi eksekusi kebijakan dalam rangka mencapai tujuan Negara. Dinamika persaingan politik dalam pemerintahan selalu tercipta sebelum dan/atau setelah pemilihan umum.

Persaingan antara legislatif dengan eksekutif pasca pemilihan umum

\footnotetext{
${ }^{3}$ Ibid. hlm. 286
}

terjadi antara Dewan Perwakilan Rakyat (Partai Politik) dengan Kepala Negara (Presiden dan/atau wakil Presiden) dan/atau Kepala Daerah (Gubernur, Bupati dan/atau Walikota). Oleh karena itu, konsepsi checks and balances dibutuhkan dalam penyelenggaraan Negara dalam rangka menjaga stabilitas pemerintahan dan juga stabilitas politik. Sistem checks and balances memungkinkan terhindarnya saling adu kekuasaan antar lembaga kekuasaan yang dapat menimbulkan konflik kekuasaan dan mengancam stabilitas pemerintahan.

Sistem checks and balances menciptakan pemisahan kekuasaan dengan batas-batas cabang kekuasaan yang telah ditentukan dengan turut campur dalam cabang kekuasaan satu dengan lainnya. ${ }^{4}$ Konflik kekuasaan timbul akibat ketidakpuasan antarlembaga (legislatif dan eksekutif) yang lahir dari kekuasaan dan kewenangan secara konstitusional dapat mencampuri kekuasaan dan kewenangan lembaga lainnya. Persoalan antara legislatif dan eksekutif dalam sistem pemerintahan di Indonesia pada akhirnya selalu dipengaruhi oleh elit politik. Elit politik merujuk pada orang-orang yang terpilih dalam pemilihan umum untuk menduduki jabatan politik tertentu serta orang-orang yang menjadi pimpinan partai politik. ${ }^{5}$ Orang-orang yang menduduki jabatan politik secara normatif orang yang terpilih dari mekanisme politik baik untuk jabatan kepala Negara (Presiden dan/atau wakil

\footnotetext{
${ }^{4}$ Ibid. hlm. 284

5 Syamsuddin Haris, Konflik Presiden-DPR Dan Dilema Transisi Demokrasi Di Indonesia, Cet. Ke-1 (Jakarta: Pustaka Utama Grafiti, 2007). hlm. 18
} 
Presiden) dan Parlemen (Dewan Perwakilan Rakyat) yang menduduki jabatan tersebut dengan kekuasaan dan kewenangan yang melekat pada jabatannya. $^{6}$

Berdasarkan konsepsi tersebut, dalam menjaga stabilitas pemerintah pasca pemilihan umum di Indonesia dibutuhkan konsolidasi politik antarjabatan politik berdasarkan mekanisme politik dan kekuasaan normatif. Oleh karena itu, sistem checks and balances dalam penyelenggaraan pemerintahan menjadi landasan stabilitas politik dan stabilitas pemerintahan. Pergeseran konsepsi checks and balances dari separation of power ke division of power menjadi awal konflik kekuasaan yang mengakibatkan elit politik pasca pemilihan umum di Indonesia harus saling berkonsolidasi untuk menjaga stabilitas politik. Implikasi dari konsolidasi elit politik adalah membentuk kesamaan visi, misi dan tujuan para elit politik dalam bingkai koalisi pemerintah.

Konsep koalisi dalam sistem ketatanegaraan Indonesia secara tersirat diakui dan konstitusional seperti yang terangkum dalam ketentuan UndangUndang Dasar 1945 mengenai calon Presiden dan/atau wakil Presiden yang diusulkan oleh gabungan partai politik. Usulan Presiden dan/atau wakil Presiden oleh partai politik secara tersirat dan normatif menunjukan Negara Indonesia menganut sistem checks and balances. Akan tetapi bagaimana membangun

\footnotetext{
${ }^{6}$ Fuqoha Fuqoha, "Etika Rangkap Jabatan Dalam Penyelenggaraan Negara Ditinjau Dalam Prinsip Demokrasi Konstitusional," Sawala Vol. 3, No. 3 (2015): 29-41, http://ejurnal.lppmunsera.org/index.php/Sawala/article/view/ 288. hlm. 32
}

sistem checks and balances sebelum dan setelah pemilihan umum tersebut menjadi persoalan yang dapat menciptakan konflik politik. Konflik politik berpusat pada hubungan antara kekuasaan, pengaruh dan kewenangan masingmasing pihak yang bertikai. ${ }^{7}$ Implikasi terhadap usulan dari gabungan partai politik dalam bingkai demokrasi menciptakan peluang pada demokrasi transaksional antar elit politik.

Berdasarkan kenyataan tersebut, tulisan ini ingin mengkaji secara empiris dinamika stabilitas politik pasca pemilihan umum di Indonesia dalam dua sudut yakni konsep checks and balances dan/atau demokrasi transaksional. Sistem ketatanegaraan Indonesia secara konstitusional menganut sistem checks and balances untuk menjaga stabilitas pemerintahan dan/atau stabilitas politik pasca pemilihan umum. Akan tetapi, disisi lain untuk dapat mewujudkan sistem checks and balances tersebut dimungkinkan terjadinya transaksional antar elit politik dibalik prinsip demokrasi. Penelitian ini membatasi penelitian terhadap lembaga legislatif dan eksekutif yang secara konstitusional telah ada separation of power dan/atau division of power.

\section{B. METODE PENELITIAN}

Metode penelitian yang digunakan yaitu model penilitan kualitatif yang bersifat deskriptif analitis melalui pengumpulan data selengkap mungkin untuk menggambarkan fakta-fakta secara sistematis dan terintegrasi. Penelitian ini mendeskripsikan secara intensif suatu

\footnotetext{
${ }^{7}$ Haris, Konflik Presiden-DPR Dan Dilema Transisi Demokrasi Di Indonesia.Loc. cit.
} 
fenomena, latar belakang, interaksi sosial hingga dampak yang ditimbulkan. John Creswell mengemukakan bahwa penelitian kualitatif mengarah pada eksplorasi suatu makna yang timbul dari dinamika sosial. ${ }^{8}$ Fokus penelitian ini adalah konsepsi checks and balances dan demokrasi transaksional. Sumber data yang dihimpun diambil dari studi kepustakaan melalui peraturan perundang-undangan, buku, jurnal dan berita dari berbagai sumber baik cetak maupun online.

\section{HASIL DAN PEMBAHASAN}

\section{Stabilitas Pemerintahan dalam Konsep Trias Politika}

Sistem ketatanegaraan Indonesia menegaskan dalam rangka penyelenggaraan negara mengandung prinsip demokrasi konstitusional. Dalam rangka mewujudkan pemerintahan yang stabil guna tercapainya tujuan dan citacita bangsa dan Negara maka diadakan pembatasan kekuasaan. Ketentuan konstitusional tersebut dirumuskan dalam rangka pemenuhan kepastian hukum penyelenggaraan pemerintahan yang dibatasi konstitusi. Dengan diaturnya ketentuan terkait fungsi dan kewenangannya, maka penyelenggaraan pemerintahan diharapkan dapat menciptakan stabilitas pemerintahan.

Prinsip demokrasi konstitusional dalam penyelenggaraan negara menggambarkan bahwa kekuasaan pemerintahan dan kebebasan masyarakat dibatasi oleh konstitusi. Prinsip demokrasi memberikan ruang atau

8 John W. Creswell, Research Design, Pendekatan Kualitatif, Kuantitatif Dan Mixed, Third Ed. (Yogyakarta: Pustaka Pelajar, 2015). hlm. 4 kebebasan bagi seluruh unsur negara, baik bagi pemerintah maupun bagi rakyat, untuk melaksanakan tindakantindakan sesuai dengan kepentingan maupun kebutuhan dalam bernegara. ${ }^{9}$ Dengan demikian, konsep pembatasan kekuasaan merupakan bagian dari demokrasi konstitusional dalam bentuk separation of power dan/atau division of power untuk mewujudkan stabilitas pemerintahan yang demokratis di Indonesia.

Stabilitas pemerintahan dapat dimaknai sebagai suatu penyelenggaraan pemerintahan yang kuat. Memaknai stabilitas pemerintahan seperti dikemukakan Firdaus bahwasanya stabilitas merujuk pada keseimbangan sedangkan pemerintahan merujuk pada penyelenggaraan fungsi kekuasaan Negara dalam kekuasaan legislatif, eksekutif dan yudikatif. ${ }^{10}$ Dengan demikian konsepsi stabilitas pemerintahan dalam sistem ketatanegaraan Indonesia menggambarkan suatu sistem penyelenggaraan pemerintahan yang seimbang antara institusi-institusi kekuasaan yang diatur dalam konstitusi Negara Republik Indonesia.

Institusi kekuasaan yang diatur dalam konstitusi Indonesia menggambarkan konsep trias politika yang dikemukakan oleh John Locke dan

9 Fuqoha Fuqoha, "Peraturan Daerah Bermuatan Syariat Islam Ditinjau Dari Prinsip Demokrasi Konstitusional," Al-Daulah: Jurnal Hukum Dan Perundangan Islam Vol. 8, No. 1 (2018): 1-24, http://jurnalfsh.uinsby.ac.id/index.php/aldaulah/articl e/view/657. hlm. 11

10 Firdaus, Constitutional Engineering, Desain Stabilitas Pemerintahan \& Sistem Kepartaian (Bandung: Yrama Widya, 2015). hlm. 17-18 
Mostesquieu. Namun demikian, doktrin trias politika dalam sistem ketatanegaraan Indonesia lebih sesuai dengan pemikiran Montesquieu yang membagi kekuasaan pemerintahan dalam tiga cabang yaitu legislatif, eksekutif dan yudikatif. ${ }^{11}$ Konsep trias politika tersebut tercermin dalam konstitusi dalam BAB III tentang Kekuasaan Pemerintahan Negara yang memberikan kekuasaan pada lembaga "eksekutif". Selanjutnya kekuasaan "legislatif" tertuang dalam BAB VII tentang Dewan Perwakilan Rakyat (DPR) dan BAB VIIA tentang Dewan Perwakilan Daerah (DPD), serta institusi "yudikatif" yang dijamin dalam BAB IX tentang Kekuasaan Kehakiman.

Konsep trias politika merupakan doktrin konstitusional mengenai pemisahan kekuasaan dalam cabang legislatif, eksekutif dan yudikatif. Dalam hal ini, legislatif membuat hukum, eksekutif menjalankan hukum dan yudikatif menafsirkan hukum. Dengan demikian, konsep trias politika tidak terlepas dari prinsip checks and balances dimana Negara membagi kekuasaan dan tugas pada tiap-tiap cabang dan membatasi tindakan masing-masing cabang. ${ }^{12}$

Dalam prinsipnya esensi stabilitas pemerintahan tidak lepas dari refleksi stabilitas politik yang menjadi salah satu instrument penyelenggaraan pemerintahan. Oleh karena itu, konsep trias politika tidak diartikan sebagai separation of power melainkan division of power dengan maksud bahwa

11 Romi Librayanto, Trias Politica Dalam Struktur Ketatanegaraan Indonesia, Cet. Ke-1 (Makasar: PuKAP - Indonesia, 2008). hlm. 19

${ }^{12}$ Ibid. hlm. 23 kekuasaan dibedakan dari sifatnya, akan tetapi saling bekerjasama antarkekuasaan untuk kelancaran dan tercapainya tujuan pemerintahan. ${ }^{13}$ Namun demikian, konsepsi checks and balances akan sulit terwujud, Juan Linz menyatakan bahwa pemisahan kekuasaan antara lembaga eksekutif dengan legislatif didalam sistem presidensial cenderung menimbulkan polarisasi dan instabilitas politik. ${ }^{14}$

Sistem checks and balances menciptakan pemisahan kekuasaan dengan batas-batas cabang kekuasaan yang telah ditentukan dengan turut campur dalam cabang kekuasaan satu dengan lainnya. ${ }^{15}$ Dengan demikian, konsep trias politika dalam menjaga stabilitas pemerintahan dapat terancam bila prinsip checkas and balances tidak terwujud dalam penyelenggaraan pemerintahan. Polarisasi yang diungkapkan Linz dalam penyelenggaraan pemerintahan presidensial di Indonesia akan berimplikasi ancaman terhadap stabilitas politik maupun stabilitas pemerintahan.

Dalam mewujudkan stabilitas pemerintahan dalam konsep trias politika dan prinsip checks and balances, maka harus ada konsolidasi yang oleh Larry Diamond diartikan sebagai tahap di mana para aktor politik (di kalangan elit maupun massa) konsep Negara demokrasi dalam hal ini Negara Indonesia menganut konsep demokrasi konstitusional sebagai satu jalan untuk

\footnotetext{
${ }^{13}$ Ibid. hlm. 24

${ }^{14}$ Syamsuddin Haris et al., "Pemilu Nasional Serentak 2019," ed. Syamsuddin Haris, Cet. I (Yogyakarta: Pustaka Pelajar, 2016). hlm. 3

${ }^{15}$ Budiardjo, Dasar-Dasar Ilmu Politik.Loc. cit.
} 
mewujudkan cita-cita bangsa. ${ }^{16}$ Oleh karena itu, pengejawantahan trias politika dalam sistem ketatanegaraan Indonesia menjadi suatu hal yang esensial dalam mewujudkan pemerintahan yang stabil serta mewujudkan cita-cita bangsa dan Negara.

\section{Demokrasi Transaksional : Ancaman Stabilitas Politik dan Pemerintahan di Indonesia}

Stabilitas politik dan pemerintah dapat dibangun dengan keselarasan antar pemegang kekuasaan politik dan pemerintah. Konsepsi stabilitas tersebut terbentuk dalam konsep checks and balances sebagai prinsip penyelengaraan yang berimbang antara legislatif, eksekutif dan yudikatif. Konsepsi checks and balances tidak terlepas dari kekuasaan (separation of power dan/atau division of power) yang memberikan masing-masing institusi atau lembaga kekuasaan dan kewenangan yang melekat pada jabatan-jabatan yang didudukinya. Dalam sistem pemerintahan di Indonesia, maka prinsip checks and balances tersebut dibagi kapada legislatif (MPR, DPR, DPD dan/atau DPRD) dengan eksekutif (Presiden dan/atau Wakil Presiden, Kepala daerah beserta kementerian dan/atau lembaga dibawah kekuasaan Presiden dan/atau Kepala Daerah) dan yudikatif (Kekuasaan Kehakiman).

16 Arif Wijaya, "Demokrasi Dalam Sejarah Ketatanegaraan Republik Indonesia," Al-Daulah: Jurnal Hukum Dan Perundangan Islam 4, no. 01 (2014): 136-58, https://doi.org/10.15642/ad.2014.4.01.136-158. hlm. 153
Prinsip demokrasi di Indonesia memberikan peluang terselenggaranya pemerintahan yang lebih dinamis antar lembaga satu dengan lembaga lain, bahkan lembaga satu dapat mendominasi lembaga yang lain didasarkan pada kekuatan dan kekuasaan politik yang dimiliki. Sehingga pemisahan kekuasaan secara konstitusional menjadi landasan yuridis terhadap setiap kewenangan yang diberikan kepada institusi baik DPR dan/atau DPRD dengan Presiden dan/atau Kepala Daerah. Kekuasaan oleh Harold D. Laswell dan Abraham Kaplan diartikan sebagai hubungan yang menentukan tindakan sendiri dan/atau kelompok agar sesuai dengan tujuannya. $^{17}$

Pasca pemilihan umum di Indonesia baik di pusat maupun di daerah akan selalu diwarnai dengan persoalan kekuasaan antara legislatif dan eksekutif. Pemegang kekuasaan akan selalu ingin tampil lebih dominan, apabila berbeda patron atau latar belakang dukungan politik antara penguasa di eksekutif dengan penguasa di legislatif. Sehingga untuk menciptakan stabilitas politik dan pemerintah, dituangkan ketentuan dukungan partai politik sebagai instrumen politik dalam sistem pemerintahan di Indonesia. Dukungan partai politik pada penguasa eksekutif sebagai bagian dari upaya penyamaan visi dan misi kekuasaan, sehingga masing-masing institusi tidak saling mempengaruhi dan mencampuri kekuasaan diluar institusi tersebut.

\footnotetext{
${ }^{17}$ Miriam Budiardjo, Demokrasi Di Indonesia : Antara Demokrasi Parlementer Dan Demokrasi Pancasila, Cet. Ke.2 (Jakarta: Gramedia Pustaka Utama, 1996). hlm. 92
} 


\begin{abstract}
Dalam tatanan kekuasaan dibedakan antara ruang lingkup kekuasaan (scope of power) dan jangkauan kekuasaan (domain of power) dimana kedua model kekuasaan tersebut akan melahirkan wewenang (authority) dan keabsahan (legitimacy). ${ }^{18}$ Dalam pandangan Jack Hagel, scope of power menunjukan objek kekuasaan sedangkan domain of power menunjukan subjek kekuasaan. ${ }^{19}$ Sistem ketatanegaran Indonesia dalam penyelenggaraan Negara sebagaimana diatur dalam konstitusi dan perturan perundang-undangan bahwa kekuasaan legislatif memiliki 3 (tiga) objek kekuasaan atau kewenangan antara lain legislasi, pengawasan dan anggaran. Sedangkan subjek kekuasaannya adalah eksekutif yang melaksanakan ketentuan yang ditetapkan oleh legislatif melalui undang-undang (fungsi legislasi) dan menggunakan anggaran (fungsi anggaran).
\end{abstract}

Sistem penyelenggaraan pemerintahan di Indonesia menganut prinsip demokrasi. Affan Gaffar mengemukakan bahwa demokrasi sebagai perwujudan kehidupan politik praktis dalam sistem politik yang diselenggarakan. $^{20}$ Dalam konsepsi Negara demokrasi dikenal istilah demokrasi transformatif dan demokrasi transaksional. Demokrasi transformatif melahirkan partisipasi dalam pemilihan umum untuk memilih wakil rakyat secara cerdas dengan harapan dapat menjalankan pemerintahan secara

${ }^{18}$ Ibid. hlm. 89

${ }^{19}$ Fuqoha, Op. cit. hlm.35-36

20 Afan Gaffar, Politik Indonesia, Transisi Menuju Demokrasi, Cet. Ke-VI (Yogyakarta: Pustaka Pelajar, 2006). hlm. 3-5 transformatif sehingga mendapatkan hasil baik yang dapat dinikmati rakyat. Sedangkan demokrasi transaksional pemilihan wakil rakyat ditentukan oleh partai politik atau orang-orang politik yang pada akhirnya wakil terpilih akan membentuk koalisi atau transaksional dengan pemimpin politik lainnya. ${ }^{21}$

Dalam menciptakan stabilitas pemerintahan dalam prinsip demokrasi, maka konsekuensinya adalah terbentuknya checks and balances dalam penyelenggaraan pemerintahan. Penyelenggaraan Negara Indonesia dalam hal pembentukan penyelenggara pemerintahan terbentuk dari konsep demokrasi melalui suatu pemilihan umum yang merupakan amanat konstitusi. Oleh karena itu, prinsip checks and balances dalam menjaga stabilitas pemerintahan maupun stabilitas politik mulai dibentuk jauh sebelum orang-orang yang terpilih sebagai penyelenggara melaksanakan tugas dan kewenangan.

Salah satu instrument stabilitas politik adalah partai politik sebagai wadah yang dibentuk masyarakat atas dasar persamaan kehendak dan cita-cita yang ingin diperjuangkan. ${ }^{22}$ Partai politik adalah infrastruktur politik yang mengisi lembaga Negara untuk menyelenggarakan fungsi, tugas dan wewenangnya. ${ }^{23}$ Dengan demikian stabilitas politik akan dipengaruhi oleh partai politik dalam sistem penyelenggaraan pemerintahan. Posisi dan peran partai politik telah diatur dalam

\footnotetext{
${ }^{21}$ Munir Fuady, Konsep Negara Demokrasi, Cet. Ke-1 (Bandung: Refika Aditama, 2010). hlm. 42

22 Akbar Kaelola, Kamus Istilah Politik Kontemporer, Cet. Ke-1 (Yogyakarta: Cakrawala, 2009). hlm. 221

${ }^{23}$ Firdaus, Op.cit. hlm. 14
} 
konstitusi dan peraturan perundangundangan, dimana keberadaan partai politik akan berimplikasi pada fungsi dan wewenang yang melekat pada partai politik maupun jabatan politik yang diberikan melalui partai politik.

Praktik penyelenggaraan pemerintahan yang terimplikasi dari partai politik adalah pemilihan umum yang melahirkan jabatan politik. Jabatan politik menurut Azhari merupakan jabatan yang diperoleh melalui mekanisme politik. ${ }^{24}$ Mekanisme politik merujuk pada sistem pemilihan umum yang menjadi landasan pemenuhan jabatan-jabatan politik antara lain pemilihan Presiden dan wakil Presiden, pemilihan Kepala Daerah, pemilihan Anggota Dewan Perwakilan Rakyat Republik Indonesia (DPR-RI), pemilihan Anggota Dewan Perwakilan Rakyat Daerah (DPRD) dan pemilihan Anggota Dewan Perwakilan Daerah (DPD). Sistem pemilihan umum yang diatur dalam konstitusi merupakan prinsip demokrasi, dimana dalam konsep demokrasi Indonesia menjadi demokrasi konstitusional. Dalam menjaga stabilitas pemerintahan sebelum dan sesudah pemilihan umum menjadi hal yang sangat krusial dan berpotensi mengancam stabilitas pemerintahan dan/atau stabilitas politik. Pemahaman politik baik dimasyarakat maupun pemahan politik elit-elit partai politik akan sangat mempengaruhi stabilitas politik maupun pemerintahan. Oleh karena itu, dalam

\footnotetext{
${ }^{24}$ Azhari., Mereformasi Birokrasi Publik Indonesia: Studi Perbandingan Intervensi Pejabat Politik Terhadap Pejabat Birokrasi Di Indonesia Dan Malaysia., Cet. Ke-1 (Yogyakarta: Pustaka Pelajar, 2011). hlm. 52
}

penyelenggaraan pemerintahan perlu adanya keseimbangan dalam prinsip Negara demokrasi.

Dinamika yang terjadi dalam jabatan politik di Indonesia mengarah pada jabatan politik "legislatif" dan jabatan politik "eksekutif". Hal tersebut dapat terlihat jelas dalam ketentuan konstitusi (UUD NRI Pasal 6A Ayat (2)) dan ketentuan hukum (UU No.7 Tahun 2017 Pasal 222) dalam pemilihan umum bahwa hubungan kekuasaan legislatif dan eksekutif dibentuk oleh Negara sehingga konsepsi checks and balances antara kedua kekuasaan tersebut harus terbentuk sebelum dan/atau sesudah pemilihan umum sebagai konsekuensi sistem penyelenggaraan Negara berdasarkan prinsip demokrasi konstitusional.

Sistem checks and balances menciptakan pemisahan kekuasaan dengan batas-batas cabang kekuasaan yang telah ditentukan dengan turut campur dalam cabang kekuasaan satu dengan lainnya. ${ }^{25}$ Dalam mewujudkan keseimbangan dalam konsep checks and balances maka ketentuan bahwa Presiden dan wakil Presiden (kekuasaaan eksekutif) harus diusulkan oleh partai politik (kekuasaan legislatif) menunjukan konsep demokrasi transaksional bahwa seorang calon Presiden dan wakil Presiden harus ditentukan oleh partai politik atau gabungan partai politik sebelum pemilihan umum Presiden dan wakil Presiden. Frasa gabungan partai politik menunjukan bahwa kelompokkelompok politik yang memiliki visi dan misi yang sama dan/atau kepentingan

\footnotetext{
25 Budiardjo, Dasar-Dasar Ilmu Politik.Op. cit. hlm. 284
} 
politik yang sama akan membentuk pasangan calon Presiden dan wakil Presiden yang pada akhirnya akan membentuk koalisi atau transaksional dengan pemimpin politik lainnya.

Implikasi dari demokrasi transaksional yaitu sejauh mana kekuatan koalisi dalam menjaga stablitas politik. Stabilitas politik mendakan keseimbangan antar kekuasaan politik yang dibangun oleh kelompok-kelompok koalisi politik dalam hal ini partai politik dalam suatu memperjuangkan tujuan bersama. $^{26}$ Soliditas koalisi (stabilitas politik) akan mempengaruhi stabilitas pemerintahan dalam prinsip checs and balances yang dibangun dalam rangka mewujudkan penyelenggaraan Negara secara seimbang sesuai konsep trias politika. Adanya keseimbangan antara kekuasaan legislatif, eksekutif hingga yudikatif. Perwujudan checks and balances akan sangat sulit terlihat karena sistem Negara Indonesia menganut sistem Presiden sial yang menurut Linz menyatakan bahwa pemisahan kekuasaan antara lembaga eksekutif dengan legislatif didalam sistem presidensial cenderung menimbulkan polarisasi dan instabilitas politik. $^{27}$

Sudut pandang demokrasi transaksional dalam sistem koalisi partai politik untuk mewujudkan checks and balances dapat dihindari dengan mengendepankan konsepsi demokrasi transaksional dengan model demokrasi yang tepat. Model demokrasi yang dapat digunakan antara lain demokrasi kompetitif dan demokrasi konsensus. Model demokrasi kompetitif merujuk pada suatu persoalan akan diputuskan berdasarkan suara terbanyak dan/atau melalui suatu referendum. Implikasi dari demokrasi kompetitif akan menghasilkan suatu kelompok koalisi dan kelompok oposisi. Sedangkan model demokrasi konsensus merefleksikan suatu keputusan diambil terhadap suatu masalah cenderung mengakomodir seluruh aspirasi dan/atau kepentingan yang ada, sehingga dicapai suatu keselarasan dan keharmonisan terhadap kepentingankepentingan masyarakat. ${ }^{28}$

Konsepsi checks and balance dalam sistem pemerintahan di Indonesia selaras dengan model demokrasi kompetitif. Model ini terwujud karena sistem ketatanegaraan dan konstitusi yang mewujudkan terbentuknya konsep demokrasi yang melahirkan pola cheks and balances sebelum dan sesudah pemilihan umum baik pemilihan umum Presiden dan wakil Presiden maupun pemilihan umum untuk legislatif. Seharusnya, penyelenggaraan Negara diarahkan pada model demokrasi konsensus yang mengedepankan kepentingan masyrakat dan harmonisasi pemerintahan tanpa ada kelompok yang saling menjatuhkan dalam bingkai koalisi dan oposisi yang mengakibatkan instabilitas politik dan pemerintahan.

\section{PENUTUP}

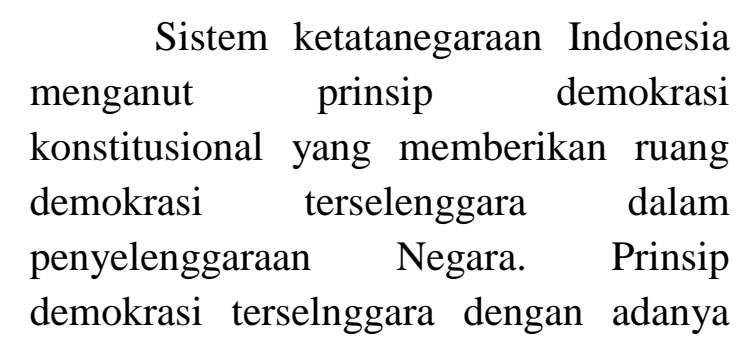

${ }^{28}$ Fuady, Op.cit. hlm. 35-36 
pemilihan umum bagi setiap warga Negara untuk terlibat dalam pemerintahan. Sistem pemilihan umum menjadi salah satu amanat konstitusi yang memberikan kesempatan setaip warga Negara untuk menduduki jabatan politik di pemerintahan melalui mekanisme yang ditetapkan konstitusi. Salah satu wadah menempati jabatan politik adalah melalui partai politik dalam sistem pemilihan umum. Dalam sistem ketatanegaraan di Indonesia menganut konsep trias politika sebagai upaya untuk membatasi kekuasaan dan kewenangan yang dimiliki oleh jabatan-jabatan politik dalam ruang kekuasaan legislatif, eksekutif dan yudikatif. Untuk itu, setiap kekuasaan dan kewenangan yang dimiliki akan dibatasi konstitusi untuk menjalankan penyelenggaraan Negara.

Kekuasaan dan kewenangan yang dimiliki oleh masing-masing institusi akan dapat saling berhadapan dan menimbulkan instabilitas pemerintahan. Dalam menghindari instabilitas pemerintahan, Negara menciptakan meknisme checks and balances bukan hanya pada saat pelaksanaan pasca terpilihnya pejabat politik. Namun, sistem ketatanegaraan Indonesia mengakomodir prinsip checks and balances sebelum pemilihan umum eksekutif diselenggarakan dengan membangun koalisi yang mendukung calon Presiden dan wakil Presiden dengan ketentuan yang ditetapkan dalam konstitusi dan mekanisme diatur melalui peraturan perundang-undangan tentang pemilihan umum.

\section{DAFTAR PUSTAKA}

\section{Buku \& Jurnal :}

Azhari. Mereformasi Birokrasi Publik Indonesia: Studi Perbandingan Intervensi Pejabat Politik Terhadap Pejabat Birokrasi Di Indonesia Dan Malaysia. Cet. Ke-1. Yogyakarta: Pustaka Pelajar, 2011.

Budiardjo, Miriam. Dasar-Dasar Ilmu Politik. Revisi. Jakarta: Gramedia Pustaka Utama, 2008.

—. Demokrasi Di Indonesia: Antara Demokrasi Parlementer Dan Demokrasi Pancasila. Cet. Ke.2. Jakarta: Gramedia Pustaka Utama, 1996.

Creswell, John W. Research Design, Pendekatan Kualitatif, Kuantitatif Dan Mixed. Third Ed. Yogyakarta: Pustaka Pelajar, 2015.

Firdaus. Constitutional Engineering, Desain Stabilitas Pemerintahan \& Sistem Kepartaian. Bandung: Yrama Widya, 2015.

Fuady, Munir. Konsep Negara Demokrasi. Cet. Ke-1. Bandung: Refika Aditama, 2010.

Fuqoha, Fuqoha. "Etika Rangkap Jabatan Dalam Penyelenggaraan Negara Ditinjau Dalam Prinsip Demokrasi Konstitusional." SawalaVol. 3, No. 3 (2015): 29-41. http://ejurnal.lppmunsera.org/index.php/Sawala/ article/view/288.

-. "Peraturan Daerah Bermuatan Syariat Islam Ditinjau Dari Prinsip Demokrasi Konstitusional." Al-Daulah: Jurnal Hukum Dan Perundangan IslamVol. 8, No. 1 (2018): 1-24. http://jurnalfsh.uinsby.ac.id/index.php/al daulah/article/view/657.

Gaffar, Afan. Politik Indonesia, Transisi Menuju Demokrasi. Cet. Ke-VI. Yogyakarta: Pustaka Pelajar, 2006.

Haris, Syamsuddin. Konflik Presiden-DPR Dan Dilema Transisi Demokrasi Di Indonesia. Cet. Ke-1. Jakarta: Pustaka Utama Grafiti, 2007.

Haris, Syamsuddin, Ramlan Surbakti, Ikrar 
Nusa Bhakti, Saldi Isra, Kuskridho Ambardi, Nico Harjanto, Didik Supriyanto, Sri Nuryanti, Sri Yanuarti, and Moch. Nurhasim. "Pemilu Nasional Serentak 2019." edited by Syamsuddin Haris, Cet. I. Yogyakarta: Pustaka Pelajar, 2016.

Kaelola, Akbar. Kamus Istilah Politik Kontemporer. Cet. Ke-1. Yogyakarta: Cakrawala, 2009.

Librayanto, Romi. Trias Politica Dalam Struktur Ketatanegaraan Indonesia. Cet. Ke-1. Makasar: PuKAP - Indonesia, 2008.

Wijaya, Arif. "Demokrasi Dalam Sejarah Ketatanegaraan Republik Indonesia." AlDaulah: Jurnal Hukum Dan Perundangan Islam 4, no. 01 (2014): 136-58.

https://doi.org/10.15642/ad.2014.4.01.13 6-158.

\section{Undang-Undang :}

Undang-Undang Dasar Negara Republik Indonesia 1945.

Undang-Undang Nomor 14 Tahun 1985 sebagaimana telah diubah dengan Undang-Undang Nomor 3 Tahun 2009 tentang Perubahan Kedua atas Undang-Undang Nomor 14 Tahun 1985 tentang Mahkamah Agung.

Undang-Undang Nomor 24 Tahun 2003 tentang Mahkamah Konstitusi sebagaimana diubah dengan Peraturan Pemerintah Pengganti Undang-Undang Nomor 1 Tahun 2013 tentang Perubahan Kedua atas Undang-Undang Nomor 24 Tahun 2003 tentang Mahkamah Konstitusi sebagaimana ditetapkan Undang-Undang Nomor 4 Tahun 2014 tentang Penetapan Peraturan
Pemerintah Pengganti

Undang-Undang Nomor 1

Tahun 2013 tentang

Perubahan Kedua atas

Undang-Undang Nomor 24

Tahun 2003 tentang Mahkamah Konstitusi.

Undang-Undang Nomor 17 Tahun 2014 Tentang Majelis Permusyawaratn Rakyat, Dewan Perwakilan Rakyat, Dewan Perwakilan Daerah dan Dewan Perwakilan Rakyat Daerah sebagaimana diubah menjadi UndangUndang Nomor 2 Tahun 2018 Tentang Perubahan Kedua Undang-Undang Nomor 17 Tahun 2014 Tentang Majelis Permusyawaratn Rakyat, Dewan Perwakilan Rakyat, Dewan Perwakilan Daerah dan Dewan Perwakilan Rakyat Daerah.

Undang-Undang Nomor 7 Tahun 2017 Tentang Pemilihan Umum. 
